Bulut, S. (2018). Okulöncesi dönem öğretmenlerinin çocuk edebiyatı yapıtlarını seçme ölçütü olarak yazınsal karakterlere yükledikleri anlam. Ana Dili Eğitimi Dergisi, 6(3), 714-729.

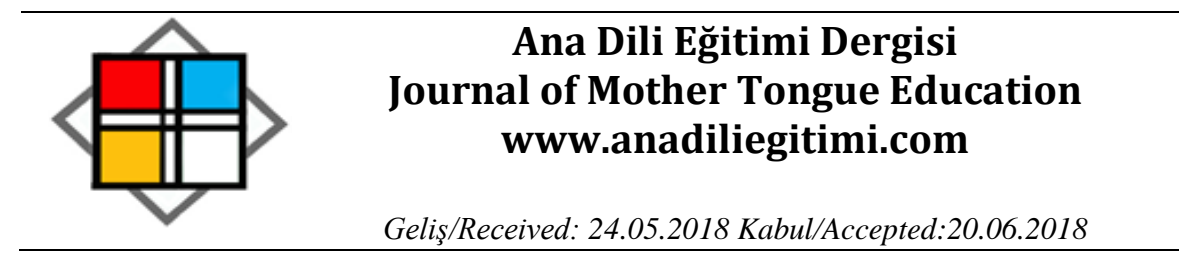

\title{
Okulöncesi Dönem Öğretmenlerinin Çocuk Edebiyatı Yapıtlarını Seçme Ölçütü Olarak Yazınsal Karakterlere Yükledikleri Anlam*
}

\begin{abstract}
Sevilay BULUT $T^{* *}$
Öz

Okulöncesi dönem öğretmenlerinin çocuklarla gerçekleştirdikleri kitap okuma odaklı etkinliklerde, ortama taşıdıkları kitapları seçerken hangi ölçütlere göre hareket ettiği önemlidir. Bu bağlamda dış yapı gibi biçimsel özelliklerin yanında iç yapı özelliklerinden olan; konu, ileti, biçem, kurgu ve karakterler gibi yazınsal öğeler metin değerlendirmelerinde göz önünde bulundurulmalıdır. Yapılan araştırmada öğretmenlerin kitap seçimlerinde özellikle karakterler bağlamında nelere dikkat ettiği üzerinde durulmuştur. Araştırma case study (durum çalışması) deseninde nitel bir çalış̧madır. Veriler betimsel kodlama yoluyla çözümlenmiş ve önce kategorilere sonra da temalara ulaşılmıştır. Çalışmada önce; "Karakterin türü”, "Gerçek yaşama aktarma”, "Olumlu karakter özellikleri” ve "Son sayfada ne mesaj veriyor?" kategorilerine ve sonrasında bu kategorilerden hareketle; "Karakter Özellikleri" ve "Davranış ve Değer Öğretimi" temalarına ulaşıııışır. Araştırma sonucunda öğretmenlerin davranış ve değer öğretimi konusunda özellikle bu amaca hizmet edebilecek olumlu karakter özellikleri taşıyan kahramanlara yöneldikleri anlaşılmışır.
\end{abstract}

Anahtar Kelimeler: Çocuk edebiyatı, kitap seçim ölçütleri, çocuk edebiyatında karakter

\section{Meanings Preschool Teachers Attribute to Literary Characters as the Criterion in Selecting Children's Literature Books}

\begin{abstract}
The criteria preschool teachers use in selecting the children's literature books they will use in book reading activities are important. In this context besides the physical features of books, content features such as theme, message, style, plot and characters should be considered in the evaluation of texts to be selected. The criteria teachers used in selecting children's literature books, by particularly focusing on what they consider in terms of characters formed the focus of the study. This research is a qualitative study designed as a case study. The data were analyzed, using descriptive coding and firstly the categories and then the themes were established. In the study the categories "Character type", "Transfer to real life", "Positive character features" and "What is the message on the last page?" were first established, and based on these categories, the themes "Character Attributes" and "Behavior and Values Education" were formed. The results showed that in terms of behavior and values education, teachers were inclined to select heroes who had positive characters traits that would be instrumental in teaching that theme.
\end{abstract}

Keywords: Children's literature, book selection criteria, character in children's literature

\footnotetext{
* Bu araştırma Sevilay BULUT’un Okulöncesi Eğitim Ortamlarında Çocuk Kitaplarıyla Gerçekleştirilen Uygulamaların Okuma Kültürü Edindirme Bağlamında İncelenmesi başlıklı tezinden yararlanılarak yapılandırılmıştır.

${ }^{* *}$ Arş. Gör. Dr, Ankara Üniversitesi, Eğitim Bilimleri Fakültesi, Türkçe ve Sosyal Bilimler Eğitimi Bölümü. Ankara. e-posta: bulut1087@gmail.com
} 


\section{Giriş}

Bir dilsel metnin edebiyat yapıtı olabilmesi için belirlenen bazı özellikleri taşıması gerekir. Metin seçiminde bu özelliklerin aranması ve ölçüt olarak değerlendirmeye katılması önemlidir. Glazer ve Williams (1979), çocuk kitaplarını; iyi bir konusu, zengin kurgusu, iyi geliştirilmiş karakterleri, önemli bir teması, sanatsal biçemi olan ve düş gücünü destekleyen dil ve anlatıma sahip yapıtlar olarak niteler (akt: Lesnik, 2004). Sever (2013), çocuk kitaplarının; yarattığı kahramanlar, ele aldığı konular ve aktardığı iletilerle fiziksel, ruhsal ve bedensel bakımdan dengeli, sağlıklı, demokratik kültürü içselleştirmiş bireylerin yetiştirilmesinde sorumluluk üstlenmesi gerektiği üzerinde durur. Bu bağlamda çocuk edebiyatında anlamı taşıyan; konu, ileti, biçem, kurgu ve karakterler gibi yazınsal öğelerin metin değerlendirmelerinde göz önünde bulundurulması önemlidir.

Bu çalışmada özellikle okulöncesi dönem öğretmenlerinin kitap okuma etkinliklerinde yararlanmak üzere seçtikleri yapıtlardaki karakterlerin seçim süreçlerine etkisini belirlemek amaçlanmıştır.

\section{Çocuk Edebiyatı Yapıtlarında Karakterler}

Kahraman ya da kişinin her şeyden önce anlatısal türlerin (roman, öykü, masal) olmazsa olmazı olduğunu vurgulayan Kıran ve Kıran (2011), kişinin anlatının merkezinde bulunduğunu ve anlatısal yapının oluşturucu öğesi olduğunu belirtir. Öykünün tutarlığı ve sürekliğinin temel kişisi olan kahraman, bir başka deyişle; anlatımın lokomotifidir. Metnin iletisi, karakterler ve onların yaşadıkları olaylar aracılığıyla verilir. Gerçek yaşamın yansımaları olan karakterler, bu özellikleriyle okurun metinle gerçek yaşam arasında ilişki kurmasında etkin rol üstlenir.

Vermeule (2013)'ye göre, anlatı karakterleri bugüne kadar icat edilmiş en büyük pratik akıl yürütme şemalarıdır. Ahlaki meseleleri çözmek, yeni duygusal durumları uygulamak, ortamdaki kültürel bilgi yığınları için kestirme bir yol olarak karakterlerden yararlanılır. Pratik akıl yürütme şemaları olarak düşünüldüğünde karakterler; büyük bir hızla değişen dünyaya, karmaşıklaşan ilişkilere ve her geçen gün artan bilgi birikimine ayak uydurmada bir araç olarak kullanılabilir. Kurmaca yazarları, bu araçları büyük bir özenle geliştirmiştir. Metnin içerdiği deneyimler, karakterler aracılığıyla belli bir yer ve zaman içinde sunulur. Ancak bu sunum sırasında kahramanın bakış açısı önemli bir yere sahiptir.

Okuduğunu anlama alanında yapılan çalışmalar, metnin anlamlandırılması sırasında okurun kendini konumlandırmasına ilişkin ortaklaşan veriler sunmuştur. Bu araştırmalarda sıklıkla dile getirilen kavramlarsa eşduyum (empati), duygusal bulaşma ve sempatidir. Birbiriyle ilgili olsa da temelde birbirinden ayrılan özelliklere sahip bu kavramlar, okurun metinle karakterler aracılığıyla ilişki kurmasına odaklanır. Eşduyumu karmaşık bir bilişsel ve duyuşsal süreç olarak nitelendiren Coplan (2004), bir başkasıyla eşduyum kurulduğunda, onun psikolojik bakış açısının benimsendiği ve 
Okulöncesi Dönem Öğretmenlerinin Çocuk Edebiyatı Yapıtlarını Seçme Ölçütü Olarak Yazınsal Karakterlere Yükledikleri Anlam

yaşadıklarının bir dereceye kadar düş gücüyle yaşanabileceğini dile getirir. Black, Turner ve Bower (1979); Rinck ve Bower (1995)'in yetişkinlerle yaptığı çalışmaların yanı sıra Rall ve Harris (2000); 3-4 yaşındaki çocuklarla öykülerde geçen gösteren/gösterilen (diectic) eylemlerin (getir/götür, gel/git vb.) -ki bu eylemler hareketin referans noktasından mı yoksa referans noktasına doğru mu olduğunu ifade etmede kullanılır- üzerine çalışmalar yapmıştır. Bu çalışmalarda okur; bir bakış açısı benimsemekte, yeni bilgiler bu bakış açısından tanımlandığında daha hızlı ve doğru biçimde alınmakta ve girdi bu bakış açısıyla uyumlu hale gelecek biçimde yeniden kodlanmaktadır. Buradan yola çıkarak okuyanın ya da dinleyenin, öyküyü kendi bakış açısına mı yoksa kahramanınkine göre mi anlamlandırdığı ortaya çıkarılmıştır. Yetişkinlerle benzer biçimde, çocuklar da bu yönde sorulan sorulara öykü kahramanının konumuna göre yanıt vermiştir. Rall ve Harris (2000) bu durumu ödünç alınmış bakış açısı olarak nitelendirir.

Kurmaca dünya, öykü boyunca özdeşim kurulan kahramanın gözünden görülür. Manguel (2017), Alice Harikalar Diyarında'yı ilk okuduğunda Alice'nin yol arkadaşı olduğunu, çıktıkları bu yolculukta her şeyi gerçek olarak nitelediğini, tavşan deliğinden düşmenin bir otobüse binmek kadar doğal geldiğini ifade etmektedir. Bu durumu açıklarken Vermeule (2013), kahramanların çıktıkları yolculukta okurlarını/dinleyenlerini yanlarına aldıklarını, bu yol arkadaşlığı sırasında okurların edilgin olmadığını ve gerçekte yaşanan olaylarla aynı duyguların hissedildiğini dile getirir. Bu durum kurmaca karakterlerin okur üzerinde ne denli etkili olabileceğini ve bu yazınsal serüvende okurlarını nasıl başka dünyalara götürebildiğini gösterir. Okur, kendini kahramanla özdeşleştirir, bu noktada önemli olanın çocuğun olumsuz etkileneceği değil, izlemek isteyeceği bir kahraman yaratılmasıdır. Bu ise yazar için önemli ancak aynı zamanda zor bir çabadır (Neville, 1967).

Anlatı kahramanı, yazarın gerçeklikle kurduğu ilişkiden doğar. Kurmaca kahramanı; bir kişinin, başka bir deyişle gerçekte var olan bir insanın, belirgin ya da örtük özellikleriyle donanmış kurgusal bir kişidir. Bu nedenle kimi okur, kahramanları gerçek kişilerle özdeşleştirme eğilimi gösterir (Kıran ve Kıran, 2011). Kitap kahramanlarıyla özdeşim kurma çocuk edebiyatı yapıtlarının yaratım sürecinde önemli bir yere sahiptir. Karakterler, çocukların kitapları tekrar tekrar dinlemelerini ya da okumalarını istemelerinde en temel öğelerdir. Bunun gerçekleşebilmesi içinse güçlü ve inandırıcı karakterlerin olması önemlidir (Lukens ve diğerleri, 2013). Özdemir (2011), karakter geliştirmede doğrudan yani kişilerin görünüşlerini betimleme, iç dünyalarını sergileme ya da dolaylı yani eylem içinde yansıtma, konuşturma vb. yollarının kullanıldığını dile getirmiştir. Bunları anlatma ve gösterme adları altında gruplandırmanın uygun olabileceğini de belirtir. Okulöncesinde kahramanlar, fiziksel özellikleriyle geliştirilirken onlara sözleri ve davranışlarıyla da kişilik kazandırılabilmektedir. Dilsel metnin fazla ayrıntıya yer vermeyecek yapıda olması, karakterlerin uzun betimlemelerle anlatılmasını olanaksız kılmaktadır. Bu da yazarı, karakterlerin düşünceleri ve kişisel özelliklerini kahramanın davranışları 
üzerinden açıklamaya yönlendirir. Dış görünüşlerinin anlatılması içinse gölge metinler olarak nitelenen görseller işe koşulur.

“Çocuğun kitaptaki olumlu karakterlerle özdeşim kurabilmesi, anlatının içine girebilmesi, yazarın betimlediği karakterlerin inandırıcı, güvenilir, günlük yaşamdaki kadar gerçekçi ve çocukla aynı yaş düzeyinde olmasına bağııdır" (Karatay, 2014: 103). Nas (2014), çocuk edebiyatı yapıtlarında sunulan karakterlerin insanın güçlü-zayıf, olumlu-olumsuz ve çelişkili yanlarını yansıtması gerektiğine; insanın üstün ve yenilmez olarak değil, idealize edilmeden gerçek bir insan örneği olarak geliştirilmesinin önemine vurgu yapar. Yazarların karakterleri yaratırken onlarda olmasını arzu ettikleri özellikleri değil; sıradan bir çocukta var olan ve hatta ideal bir çocukta olmayan özellikleri koyması, karakteri gerçekçi ve dikkat çekici kılacaktır. Bununla birlikte karakterlerin öykü boyunca değişim geçirmeleri ve bu değişimlerin inandırıcı olması da aranan özellikler arasındadır.

Çocukların sempati duyabileceği hayvan karakterler de öykülerde kahraman olarak karşımıza çıkmaktadır. Bu da fiziksel olmasa da duygusal anlamda bir özdeşime olanak sağlayacaktır. Bunun yanında, kahramanların hayvanlardan seçilmesi herhangi bir cinsiyet ya da ırk vurgusu taşımadığından ayrışmaların da önüne geçebilmektedir. Basit gibi görünen karakter seçiminin, pek çok açıdan anlatıların okurun zihninde anlam kazanmasına olanak tanıyan önemli özellikler taşıdığı anlaşıımaktadır. Kitap kahramanlarının okuma eyleminin niteliğini de etkilediğini dile getiren Sever (2013)'e göre, iyi geliştirilmiş kişilik özellikleriyle gerçeklik duygusu uyandıran, çocuğun kahramanla tanışma, karşılaşma isteğini yoğunlaştıran kitaplar, okuma kültürü edindirme sürecinde önemli bir işlevi yerine getirir.

Araştırmada yanıt aranan temel soru; öğretmenlerin kitap okuma odaklı etkinliklerde çocuklarla buluşturdukları kitapları seçme süreçlerinde bir ölçüt olarak karaktere yükledikleri anlamların neler olduğudur.

\section{Yöntem}

\section{Araştırmanın Deseni}

Bu araştırma; öğretmenlerin okulöncesi eğitim ortamlarında etkinlik yaparken yararlandıkları kitaplarda karakterler bağlamında aradıkları niteliklerin ve bu yöndeki seçim ölçütlerinin neler olduğuyla sınırlandırılmıştır. Belirlenen bu sınırlı sistemin ayrıntılı betimlenmesini sağlamak için araştırma durum çalışması (case study) olarak desenlenmiş nitel bir çalışmadır. Durum çalışması nitel araştırmalarda sıklıkla başvurulan bir araştırma desenidir ve araştırmacının bu deseni kullanmadaki amacı bir durumu kavrama, keşfetme, yorumlama gereksinimi duymasıdır. Bütünsel bir betimleme ve açıklama bulmaya odaklanılan durum çalışmasında duruma ilişkin önemli etkenlerin birbiriyle ilişkisini ortaya çıkarmak amaçlanır (Merriam, 2009). 
Okulöncesi Dönem Öğretmenlerinin Çocuk Edebiyatı Yapıtlarını Seçme Ölçütü Olarak Yazınsal Karakterlere Yükledikleri Anlam

Yıldırım ve Şimşek (2011), nitel durum çalışmasının en temel özelliğinin bir ya da birden çok durumun derinlemesine incelenmesine olanak sağlaması olduğunu dile getirir. İncelenen duruma etki eden ortam özellikleri, bireyler, süreçler ve benzeri etkenlerin bütüncül bir yaklaşımla ele alındığını ve ilgili durumu nasıl etkilediğine odaklanıldığını da belirtir. Creswell (2013), durum çalışmasıyla gerçek yaşam bağlamında sınırları belirlenmiş bir ya da birden çok sistem veya durumu ele almak ve bunlarla ilgili bilgi sağlamak için gözlem, görüşme, görsel-işitsel kayıt gibi araçlara başvurulduğunu, bu yolla ayrıntılı bir durum betimlemesi sağlandığını vurgulamıştır.

\section{Çalışma Grubu}

Bu çalışmada yer alacak öğretmenlerin belirlenmesi için amaçlı örnekleme türlerinden maksimum çeşitlilik örnekleme kullanılmıştır. Maksimum çeşitlilik örneklemesinde amaç; çalışılan soruna taraf olabilecek bireylerin çeşitliliğini en üst düzeyde yansıtmaktır (Yıldırım ve Şimşek, 2011). Çalışmalarda maksimum veri çeşitliliğinin tercih edilme nedeni, olabildiğince farklı katılımcıdan çok yönlü görüş alabilmektir (Creswell, 2005). Merriam (2013), amaçlı örnekleme için seçilen ölçütün doğrudan çalışmanın amacını yansıttığını ve bilgi bakımından zengin durumların tanımlanmasına kılavuzluk ettiğini belirtir. Patton (2014), her ne çalışılırsa çalışılsın verinin her zaman olası en düşük analiz birimi seviyesinde toplanmasının uygun olacağını dile getirir. Bu kapsamda, Ankara merkez ilçelerindeki ilk ve ortaokullarda okulöncesi öğretmeni olarak görev yapan 30 (otuz) öğretmen çalışma grubuna katılmıştır. Farklı ilçelerdeki farklı dinamiklere sahip okullarda görev yapan öğretmenlere ulaşmak, araştırmada zengin veri sağlamak ve durumun çeşitli biçimlerde örneklendirilmesi için önemli görülmüştür.

\section{Verilerin Toplanması}

Durum çalışmalarında, bir ya da birkaç durumu belirli sınırlar içinde bütüncül olarak ve derinlemesine çözümleme temele alınmaktadır. Veri toplama sürecinde de bu amaç doğrultusunda çok boyutlu, farklı derinlikte ve türde veri toplama teknikleri kullanılmaktadır. Araştırma verileri, öğretmenlerle yapılan görüşmeler ve sınıf içi gözlemlerle elde edilmiştir. Gözlem ve gözlem sırasında tutulan notlardan verilerin yorumlanması aşamasında yararlanılmıştır.

Tablo 1. Araştırma Verilerinin Toplanması Süreci

Alanyazın Taraması

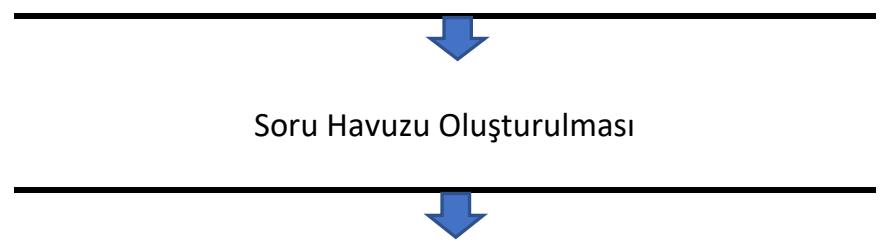


Görüşme Sorularının Belirlenmesi

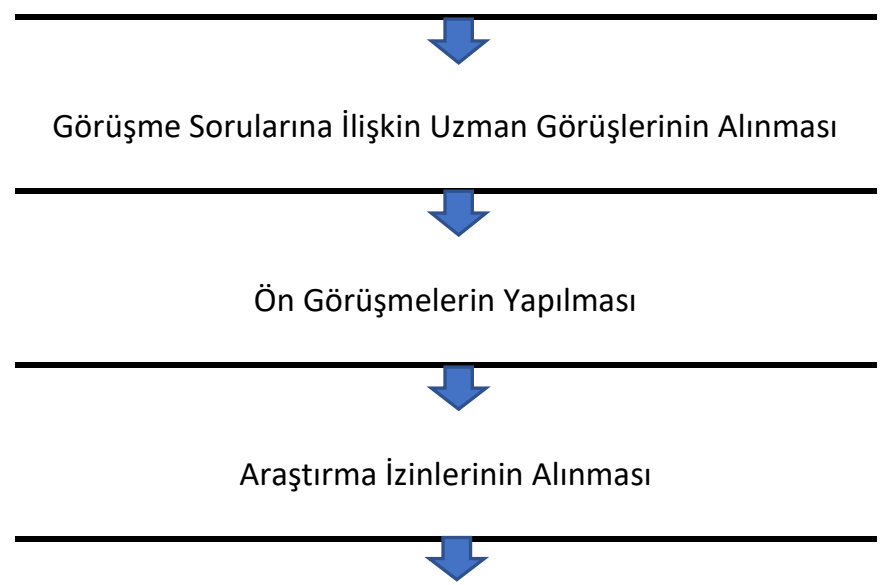

Görüşmelerin ve Gözlemlerin Gerçekleştirilmesi

Bu çalışmada nitel araştırmalarda sıklıkla başvurulan bir veri toplama yöntemi olan "görüşme" tercih edilmiştir. Patton (2014), görüşmelerin insanlarda doğrudan gözlenemeyen durumları ortaya çıkarmada kullanılan bir yöntem olduğunu vurgular. Bir insanın aklından geçenleri açığa çıkarmak, geçmiş yaşantılarına ilişkin bilgi edinmek, olaylara yükledikleri anlamları ortaya koymak gibi amaçlar için görüşme yöntemine başvurulmaktadır. Araştırmada kullanılan görüşme formu araştırmacı tarafından geliştirilmiştir. Bu formun geliştirilmesinde alanyazın taramasına dayalı bir soru havuzu oluşturulmuş, buradan araştırmanın amacına uygun olan sorular seçilmiş ve düzenlemeler yapılmıştır. Ortaya çıkan form alan uzmanları tarafından değerlendirilmiş ve son biçimi verilmiştir.

\section{Verilerin Çözümlenmesi}

Verilerin çözümlenmesinde izlenen işlem basamaklarına aşağıdaki çizelgede yer verilmiştir.

Tablo 2. Araştırma Verilerinin Çözümlenmesi Süreci

Görüşme Kayıtlarının Yazıya Geçirilmesi

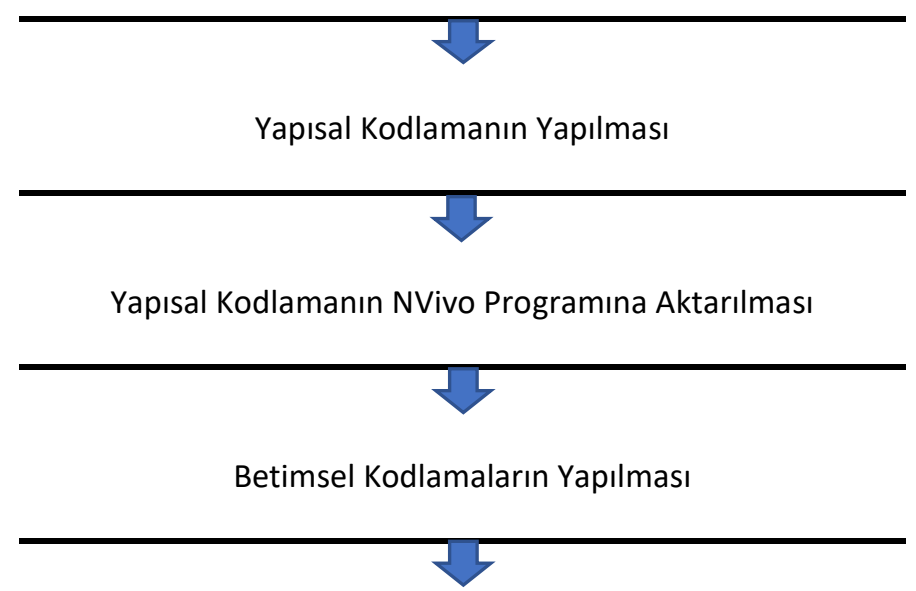


Okulöncesi Dönem Öğretmenlerinin Çocuk Edebiyatı Yapıtlarını Seçme Ölçütü Olarak Yazınsal Karakterlere Yükledikleri Anlam

Bulgular ve Yorumların Yazılması

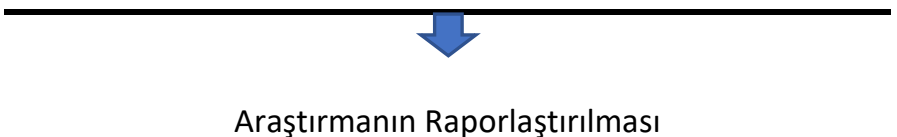

Araştırmanın Raporlaştırılması

\section{Bulgular}

Öğretmenlerin, okulöncesi eğitim ortamlarında çocuk edebiyatı yapıtlarına çeşitli amaçlarla başvurdukları araştırmalarla belirlenmiştir. Çocuk edebiyatı yapıtlarına yönelmelerinin temel sebebi, okulöncesi eğitim programının bunu gerekli kılmasıdır. Bu gereklilik öğretmenleri, çocukları çeşitli kitaplarla buluşturmaya yönlendirmiştir. Ancak program, kitapların seçimi konusunda bir belirlemede bulunmamaktadır. Bunun yanında kitapları edinmeye ilişkin resmî kurumlar tarafından herhangi bir maddi desteğin sağlanmadığı da anlaşılmaktadır. Bu durum göz önüne alındığında, eğitim ortamında çocuklarla buluşturulan kitapların karakterler bağlamında hangi ölçütler doğrultusunda seçildiği belirlenmeye değer görülmüştür. Öğretmenlere, okulöncesi eğitim ortamlarına taşınan kitapların alınmasında hangi yollara başvurulduğuna ilişkin sorular yöneltilmiş ve durumun niteliği betimlenmeye çalışılmıştır.

Karakter Özellikleri Bağlamında

Öğretmen görüşlerinin, kitap kahramanları ya da karakterleri konusunda ikiye ayrıldığı görülmüştür. Çocukların kahramanlarla özdeşim kurduğu ve seçimlerini buna göre yaptığını dile getiren öğretmenlerin yanı sıra bazı öğretmenler, kitap seçerken kahramanlara dikkat etmediklerini belirtmiştir. Karakterlerin özdeşim konusunda da etkili olduğunu savunan öğretmenler, bu konuda karakterin türünü, gerçek yaşama aktarılabilirliğini ve olumlu özelliklere sahip olup olmadığını göz önünde bulundurmaktadır.

\section{Karakterin türü}

"Hikâye kahramanının çocuk olmasını..." Ö.7

"Hayvan karakterlerini çocuklar sevdiği için ben de onları keyifle okuyorum. Onlara bir ruh vermeye çalışıyoruz ya, hayvana, çocuklar da o karakterleri çok seviyor. Benzeyen isimleri arada kullanıyorum, onlar çok hoşuna gidiyor, 'Aa, ben bu hikâyedeyim.' diye. Sınıftaki isimleri hikâye okurken değiştirebiliyorum. Dikkatini çekmek için, evet." Ö.1

"Karakter olarak değil de daha çok hayvan karakterleri çocukların ilgilerini çekiyor." 0.25

Öğretmenler, çocuklarla buluşturdukları kitapların kahramanlarının çocuk ya da hayvan olmasının aradıkları bir özellik olduğunu dile getirmiştir. Yaşamın ilk yıllarındaki çocuklar kendileri gibi küçük çocuklara ya da yavru hayvan karakterlere ilgi duyarlar, çünkü çocuk okur karmaşık yapıları ve 
ilişkileri yorumlayabilecek düzeyde değildir (Yalçın ve Aytaş, 2014; Ural, 2013). Burke ve Copenhaver (2004), kitaplarda hayvan karakterlerin yer bulmasının; kişisel olarak acı verebilecek, utanca yol açabilecek ya da tehlikeli olabilecek durumlarda duygusal mesafeyi sağlamaya yönelik olabildiğini dile getirir. Bunun yanında hayvan karakterlere; cinsiyet, ırk gibi farklılıkları da ortadan kaldırdığı ve çocuğa bu yönde çağrışım yapacak bir özellik taşımadığı için de başvurulabilmektedir.

\section{Gerçek yaşama aktarma}

Öğretmenler, karakterlerin özellikleri üzerine düşünürken gerçek yaşamla ilişkili olmasına vurgu yapmıştır. Öğretmenlere göre bir karakterin gerçek yaşamda karşılık bulması, onun okur üzerindeki etkisini artırmaktadır.

“Çok önemli. Ben mümkün olduğunca tabii ki onların yaşına uygun karakterler ve gerçek hayattan..., Çünkü gerçekten çok etkileniyorlar, kendilerini onun yerine koyabiliyorlar, oymuş gibi düşünenler oluyor. Onun için karakterlerin çok önemli olduğunu düşünüyorum." Ö.8

"Daha çok gerçeğe yakın karakterleri ya da genelde hayvan -hayvanların da insanlaştırılmış olmasına da çok fazla şey değilim- insan karakterlerin olduğu kitapları seçiyorum." Ö.24

Çocukların özdeşim yoluyla bağ kurabilmeleri için gerçek yaşamdan karakterlerin seçildiği anlaşıımaktadır. Bu anlamda, çocuk karakterlerin yer aldığı kitaplar, çocukları etkilemesi açısından öğretmenlerin seçimlerini yönlendirebilmektedir. Çocukların özdeşim kurması açısından düşünüldüğünde bazı öğretmenler, hayvan karakterler yerine insan olanları daha işlevsel bulabilmektedir.

\section{Olumlu karakter özellikleri}

Karakterin türü ve gerçeğe yakınlığının yanı sıra öğretmenler, yansıtılan kişilik özellikleri üzerinde de durmuştur. Çocuklarda bu karakterler üzerinden olumlu davranışların geliştirilebileceğini öngörmektedirler.

"Genelde olumlu karakterler seçmeye çalışıyorum, olumlu. Hayır, tabii ki o kitabın içinde olumsuz da var." Ö.9

"Dürüst, cesur, başkalarının haklarına saygılı olabilecek karakter tarzı varsa, onları örnek almalarını, o yüzden o tür şeyleri anlatmayı daha çok tercih ediyorum." Ö.18

Vermeule (2013)'nin sözünü ettiği pratik akıl yürütme şemaları kavramı burada karşımıza çıkmaktadır. Kurmaca karakterlerin temel ahlak meselelerini çözmede kestirme bir yol olarak kullanılması durumu; öğretmenlerin iyi, olumlu ve dürüst, kısaca toplum normlarına uygun birey yetiştirmede, karakterleri şema olarak kullanma eğiliminde olduğu görülmektedir. Bu yola 
Okulöncesi Dönem Öğretmenlerinin Çocuk Edebiyatı Yapıtlarını Seçme Ölçütü Olarak Yazınsal Karakterlere Yükledikleri Anlam

başvurmalarının nedeni, çocuklara kazandırılmak istenen pek çok olumlu özellik için karakterlerin kestirme bir yol olarak görülmesidir.

Kurmaca karakterlere özdeşim sağlama amacıyla başvurulması görüşünün yanı sıra çok sayıda öğretmen, kitap seçiminde kahraman ve karakter özelliklerini göz önünde bulundurmamaktadır.

"Karakterleri çok önemsemem ama şu var: Konuyla ilgili, mesela doğayla ilgili düşünürsek veya şimdi mesela kış mevsimiyle ilgili, genellikle temanın içinde kalarak götürmeye çalışıyorum." Ö.12

"Pek olmadı, karaktere bakarak çok karar vermedim." Ö.16

"Yok, öyle özel bir tercihim yok. Sevimli olmasında fayda var." Ö.17

"(Karakter seçimiyle ilgili dikkat ettiğiniz noktalar...) Yok, öyle bir şeyim olmadı." Ö.23

Öğretmenlerin büyük çoğunluğu kitaplarda konuya odaklandıklarını bu ifadeleriyle göstermiştir. Sever (2010), kurmaca öykülerde olayı sürükleyen temel öğenin 'başkişi, temel kişi, kahraman' olduğunu dile getirir. Bu anlamda çocuğun, yakınlık duymadığı bir karakterin peşinde anlatıyı izlemesi olasılığı azalmaktadır. Karakterlerin kitap seçiminde göz ardı edilmesi, çocuğun kitaba ilgi duymasında önemli bir öğenin ötelenmesi anlamına gelmektedir.

Davranışve Değer Öğretimi Bağlamında

Öğretmenler, kitap seçmede özellikle davranış ve değer öğretimine ilişkin öncelikleri olduğunu sıklıkla dile getirmişlerdir. Bu kavramlara öğretmenlerin nasıl anlamlar yükledikleri, bu süreçte neleri önceledikleri derinlemesine incelemek önemli görülmüştür.

"Son sayfada ne mesaj veriyor?"

Öğretmenlerin ifadelerinden kitaplarda aradıkları ilk özelliğin, çocuklara verdiği ileti olduğu görülmektedir. Ancak aradıkları bu iletinin, ilk bakışta görülmesini ve değer ya da davranış eğitimine yönelik olmasını beklediklerini de sözlerine eklemişlerdir.

"Şimdi değerler eğitimimiz var bizim. Değerler eğitimiyle ilgili bir mesaj veriyor mu? Benim çok kitabım var sınıfta da kullandığım. Farklı ne bulabilirsem onları tercih etmeye çalışıyorum." Ö.3

"Evet, böyle hikâye seçiyoruz ama bu hikâyenin verdiği bir mesajın olması gerekiyor. Birisinde mesela -kitaplarımıza bakarız- biri arkadaşık söylüyor, anlatıyor, biri kışı, mevsimi anlatıyor, birisi okula gittiğinde karşılaşacağı sorunları anlatıyor." Ö.18

"ilk baktım 'karakter eğitimi' yazıyor kenarında, ...ben sadece kapağa baktım, son sayfada ne mesaj veriyor ona baktım, sayfaları çevirdim resimlere baktım, hoşuma gitti. Kitabın başlığında 
da mesela; 'Cemile Karanlıktan Korkuyor', 'Cemile Kendi Başına işs Yapabiliyor' yazınca, burada vermek istediğimiz şeylere yönelik kitap herhâlde diyerekten aldım." Ö.24

Özellikle Ö.24'ün anlatısı, öğretmenlerin kitapları seçmesi konusunda izledikleri yolları özetlemesi açısından önemlidir. Kitapların karakter ya da değerler eğitimine yönelik olduğuna ilişkin bir ifade, etiket ya da açıklama içermesi o kitabın öğretmenler tarafından seçilme olasılığını yükseltmektedir. Öğretmenin dile getirdiği gibi kitabın kapağına bakılmasının ardından son sayfasında hangi iletiyi verdiği de belirtildiğinde kitap kolayca seçilebilen ve sınıf ortamına taşınabilen bir araca dönüşmektedir. Ancak bu yolla seçilen kitaplarda sınıfa taşınması sakıncalı olabilecek öğeler yer alabilmektedir. Ö.24'ün sözünü ettiği karakter eğitimi kitaplarından argo sözcüklerin çıkması kitapların kitabevine geri verilmesine neden olmuştur. Bu anlamda öğretmenlerin ölçütleri ve seçim yolları sınıf ortamına taşınacak kitapların ve bunlarla gerçekleştirilecek etkinliklerin niteliği açısından belirleyicidir.

Çocuk edebiyatı yapıtlarında iletiyle ilgili olarak öncelenmesi gereken durum, iletinin örtük ve evrensel değerlere yönelik olmasıdır. Okulöncesi dönem çocuklarıyla buluşturulacak yapıtlarda, sevginin öncelendiği ve olumlu duyguların etkin olduğu bir kurgu yaratılmalıdır. Oysa öğretmenlerin ileti konusunda ifade ettikleri öncelikler; çocuğa belli bir davranışı, açık iletiler doğrultusunda, estetik dilden ve duyuları harekete geçirme amacından uzak biçimde vermeye yöneliktir. Okulöncesinde, çocuklarda belli davranışları kazandırmaya ya da davranış değişikliği gerçekleştirmeye yönelik etkinlikler yapılmaktadır. Ancak çocuklara yönelik öykülerin yalnızca bu amaca hizmet etmesi beklenemez. Çocuk ya da yetişkin edebiyatında, sosyal ya da ahlaki konuları ele alırken yazarın öğüt vermemesi ve okur yerine yargıda bulunmaması beklenir. İyi insanların her zaman iyi ve kötü insanlarınsa her zaman kötü şeyler yapacağı yanılgısına neden olmaması da aranan bir özellik olmalıdır. Çocuk edebiyatı yazarının görevi; gerçek insanların belirli bir yerde ve zamanda nasıl hareket ettiğine ışık tutmaktır (Neville, 1967).

"Çocuğa verici bir davranış kazandırıcı olması." Ö.7

"Mesela şeyi çok seviyorum, ayıcı̆ı̆n adı Tombit miydi neydi... Onlarda hep yardımseverlik vardır. Oynarken arkadaşıyla kavga etmiştir, sonra arkadaşsız kalmıştır, nedenini araştırır, çünkü öyle davrandığı için arkadaşı olmamıştır ve canı sıkılmıştır gibi, ona benzer şeyler." Ö.23

"Renkle, şekille, kavramla ilgili bunları anlatıyorum zaten. Mesela duygularla, davranışlarla ilgili setimiz var. Belli konularda; renklerle, şekillerle, duygularla ilgili kitaplarımız var." Ö.27

"Son dönemlerde çok küçük hikâyelere, özellikle davranış geliştirmeye yönelik hikâyelere okuyup bakmamız gerekiyor." Ö.28

Yazarın amacı, çocukların kendilerini yerine koyacağı karakterleri kullanarak değer öğretmek değildir. Çocuk edebiyatı yazarı ve okurunun aslında gereksinimi olan sosyal ya da bireysel değer 
Okulöncesi Dönem Öğretmenlerinin Çocuk Edebiyatı Yapıtlarını Seçme Ölçütü Olarak Yazınsal Karakterlere Yükledikleri Anlam

duygusu geliştirebilmektir (Neville, 1967). Bu bakımdan çocuklara değerlere ilişkin farkındalık sağlama, onları tanıma ve neden değer olarak nitelendiğini gösterme amaçlanmalıdır. Mallan (2017)'ın belirttiği gibi; edebiyat ve eğitim yaşama dayalı gerçeklikleri, deneyimleri yansıtma ve model sunma yoluyla yaşamı anlamlandırma amacına sahip olsa da buradan öğretmenin ve yazarın amacının, çocukların davranışlarını değiştirmek ve önemli gördükleri değerleri benimsetmeye odaklanmak olduğu anlamı çıkarılmamalıdır.

"Özellikle değil de daha çok yardımlaşma, arkadaşlık, iyilikseverlik, o tip daha çok böyle, onları daha çok seçiyorum." Ö.10

"Mesela değerler eğitiminde biz biraz yetersiz kalmıștık. Değerler eğitiminde hikâye kitaplarımız var, değerler eğitimindeki kitapları geçen sene almayı tercih ettik çünkü gerçekten yardımlaşmayı, paylaşmayı orada güzel anlatmış. O şekilde değerlerimizi tercih ettik anlatırken. Mesela temiz olmakla ilgili bir hikâye..." Ö.14

"Geçen yıl biz sınıfımıza bir arkadaşla beraber aldık öyle, o da aldı, ben de. Mesela değerleri (sevgi, barış gibi), anlatan kitaplar gelmişti, biz onlardan aldık; dedik ki, bunlardan bizde çok yok. Değişik, mesela parktaki bir davranışı, parkta bir günü (büyükleri, küçükleri, oranın temizliğiyle alakalı), anlatıyordu, güzeldi. Sınıfımızda olmayan kitapları, olmayan konuları daha çok almaya çalışırız." Ö.15

Öğretmenler, değerlere önem verdiklerini ve değer kazandırma konusunda kitaplara başvurduklarını dile getirmişlerdir. Ancak bu değerleri belirlerken sıklıkla kendi görüş ve düşünüşlerine yatkın olanları ön plâna çıkardıklarını da ifade etmektedirler. Öğretmenlerin, değer kavramlarına yükledikleri anlamlar irdelendiğinde ulusal değerlerin önemli bir yer tuttuğu ancak evrensel değerlere de değinildiği görülmektedir.

Aslan (2013), çocuk ve gençlik edebiyatı yapıtlarının farklı duygu durumları yaratarak çeşitli değerlerin önemini çocuğa duyumsattığını dile getirmiştir. Bu anlamda, çocukları yakın çevresinden başlayarak, çeşitli duygu durumları ve olayların örneklendiği yapıtlarla karşılaştırmak önemlidir. Böylece farklı yaşantılara tanıklık edebilecek, olasılıkları değerlendirerek kendine özgü duyarlıkla, yaklaşımlar geliştirecektir.

“Çocuk kitaplarında vallahi işte bir şeyi çok beğeniyordum, 'Alper'le Burcu Serisi' bir tek onları beğeniyordum. Onun dışında ne yazar takip ediyorum ne bir şey yapıyorum. En azından birazcık da Türk kültürüne uygun olsun istiyorum. Çok mu vatansever oluyorum, çok mu milliyetçi oluyorum, orasını bilmiyorum ama bence kitap çocuğun hayatını değiştiriyor." Ö.6

"Ben bir defa şunu da çok ciddi şekilde değerlendirmek istiyorum: Biz Türk çocuklarına örf ve âdetlerimizi de öğretmeliyiz. Ben yurtdışında da gördüm; herkes kendi kültürüne o kadar çok 
güzel sahip oluyor ki. Biz kendi kültürümüzü çok iyi tanıyalım, sahip olalım. Diğer kültürleri de itmeyelim, kesinlikle onları tanıyalım, onları da kullanalım ama önce kendi kültürümüzü, önce kendimizi tanıyalım." Ö.12

"Tamam, hepimiz elhamdülillah inançlıyız ama çocuğu çok fazla başka mecralara kaydıracak kitaplar olmamalı." Ö.21

"Hocaların pek hoşuna gitmez ama ben o konuda birazcık gelenekselim; mesela Atatürk'le ilgili şiirler ezberletiyorum." 0.22

"Biraz da benim farklı düşüncem var -belki size bu ters gelebilir ama- örf ve âdetlerimize de uygun olsun diyorum. Değerler eğitimimiz de var biliyorsunuz değil mi? Orada, çocuğun bir büyüğünün elini öpmesi gerektiğini, bir bayramlaşmanın ne olduğunu öğreniyor. Öyle şeyleri de kütüphanemde bulunduruyorum ben ve değerler eğitiminde okuyoruz. Mutlaka etkisi olur." Ö.26

Çocuklar için yazan yetişkin yazarlar, yapıtlarında ya toplumun arzulanan bazı sosyo-kültürel değerlerini yansıtmaya çalışırlar ya da var olan değerler ve ideolojilere farklı bakış açıları sunarlar (Mallan, 2017). Bu görüşlerden yola çıkarak değer öğretimi ve davranış kazandırmanın özellikle kitaplar üzerinden verilmesi çabalarının öğretmenlerin çalışmalarında önemli bir yeri olduğunu söylemek olanaklıdır. Bu çabalarına yönelik olarak öğretmenlerin özellikle açık bir iletisi olan, yer yer inanç ve ahlak kavramlarına ilişkin öğeleri ve öğretileri barındıran kitaplara yöneldikleri söylenebilir. Bu bağlamda öğretmenlerin çocuklara değerler ve ideolojilere ilişkin geniş bir yelpaze sunmayı değil, arzulanan değerleri benimsetmeyi amaçladıkları söylenebilir.

Öğretmenler arasında şiddetten uzak ve evrensel değerleri tanıtıcı kitapları sınıflarına taşıdıklarını paylaşanlar da vardır. Bazı öğretmenler, çocukta olumlu duygular yeşertecek, kendine, çevresine ve diğer toplumların yaşayışlarına saygı duymasını sağlayacak türde kitaplarla karşılaşmalarına olanak tanıyan ortamlar sunmanın önemini dile getirmişlerdir.

"Belli bir ideolojiye asla ait olmasını istemiyorum." Ö.5

"Daha az şiddet içeren, şiddet hiç içermeyecek ve bunları doğruluğa, güzelliğe, olumlu davranışlara yöneltecek, ders verecek, bilgi verecek kitapları seçmeye çalışıyorum." Ö.9

"Belli bir düşünceyi empoze etmek istemiyorum hiçbir çocuğa ya da bir davranışı ya da bir kavramı verecekse gözüne soka soka versin istemiyorum. Bazı kitaplar davranış kazandırmada çok etkili oluyor gerçekten. Uyku vakti, diş fırçalama ya da kardeş kıskançlığı gibi olsun, böyle gelişimsel düzeylerine uygun güzel bir anlatım olduğunda eğitici kitaplar kullanıyorum." Ö.11 
Okulöncesi Dönem Öğretmenlerinin Çocuk Edebiyatı Yapıtlarını Seçme Ölçütü Olarak Yazınsal Karakterlere Yükledikleri Anlam

Çocuğa öğüt verecek, parmak sallayan bir ifadeyle kendi düşüncelerini benimsetmeye çalışacak yetişkin bakışı, çocukların evrensel değerleri tanıması sürecini olumsuz etkileyecektir. Bu bağlamda, dile getirilen ölçütlerin çocuk edebiyatı yapıtlarının özellikleri ve amaçlarından uzak olduğu anlaşılmaktadır. Buradan yola çıkarak öğretmenlerin, çocuk edebiyatı yapıtları ile çocuk kitapları arasındaki ayrıma dikkat etmedikleri yorumuna ulaşılabilir. Dünya çapında çocuk kitaplarının tarihçesi bir yandan eğitsel, dini ve siyasi güçlerle; diğer yandan 'özgürlük' düşüncesine ilişkin çeşitli kavramlar arasındaki gerilimi göstermektedir (Hunt, 2002). Bu anlamda çocuğu yönlendirilmesi gereken, küçük insan olarak görmek, düşünceleri ve kararlarını küçümsemek, aşılması gereken bir kabul olarak karşımıza çıkmaktadır.

\section{Sonuç ve Öneriler}

Öğretmenler kitap seçimlerinde iç ve dış yapı özelliklerine ilişkin bazı ölçütlere göre hareket ettiklerini dile getirmiştir. Öğretmenlerin yaptıkları seçimlerde öğretici metinlere yöneldikleri görülmüştür. Öğretici metinlerin kullanımıyla amaçlanan, çocuklara bazı basit kuralları öğretmek, kurallara uyan "iyi çocuk, iyi vatandaş" yetiştirmektir. Öğretmenler, açık ya da örtük olarak bu amaçlarını sıklıkla ifade etmiştir. Öğretmenler, kitapların konusunu davranış kazandırma odağına sığdırmaya çalışmakta, bunu yaparken de öğretici anlatımları yeğlemektedir. Çocuk edebiyatı yapıtlarıysa duymaya ve düşünmeye yönlendiren, bunu yaparken de çocuğu özgür kılmayı amaçlayan, iletilerini örtük biçimde ve sezdirerek vermeyi önceleyen metinler olma özelliği göstermektedir. Davranış ve yönlendirme odağında kitabı amaç kılan uygulamalar çocuk edebiyatının niteliğine ters düşmektedir.

Çocukların okuma sürecinde kitapla etkileşim kurmasında en etkili öğe olan karakterler, çocukların özdeşim kurmalarına olanak sağladığı için kitap seçiminde üzerinde durulması gereken bir başka ilkedir. Ancak öğretmenlerin kitap seçimlerinde karakterlere farklı biçimde yaklaştığı anlaşılmıştır. Öğretmenler, çocukların karakterlerle özdeşim kurduğunu, onlara öykünme eğiliminde olduğunu düşünmektedir. Bu düşüncelerinden yola çıkarak öğretmenlerin, çocuklara belirli davranışları kazandırmalarını kolaylaştıracak karakterleri içeren kitapları seçtikleri sonucuna ulaşılmıştır. Bunun yanında, karakterlerin kitap seçmede bir ölçüt olarak öncelenmediği durumların da söz konusu olduğu görülmektedir.

Öğretmenlerin kitap seçim ölçütlerinin hemen her boyutunda değindikleri konunun davranış ve değer eğitimi odağında yapılandığı anlaşılmaktadır. Çocuk edebiyatı yapıtlarının doğrudan davranış ya da değer kazandırma amacı gütmediği göz önünde bulundurulduğunda, bu yaklaşımın çocuk edebiyatı ilkeleriyle uyum sağlamayacağı söylenebilir. Çağın koşullarına uyum sağlayacak, çağdaş kültürlerle iletişim kurabilecek, evrensel ve yerel değerleri tanıyarak anlamlandırabilecek bireyler 
yetiştirme amacına ters düşen bir yaklaşımın, çocuklara okuma kültürü edindirme sürecinin önünde de önemli bir engel olduğu söylenebilir.

\section{Öneriler}

Öğretmenler okulöncesi eğitim ortamlarında çocuklarla buluşturacakları kitapları seçerken karakterlerin bir özdeşim öğesi olduğunu göz önünde bulundurması gerekir. Bunun gerçekleşebilmesi için öğretmen eğitiminde, çocuk edebiyatı öğretimine yönelik derslerde bu konunun ayrıntılı biçimde ele alınması gerekir. Hizmet içi eğitim süreçlerinin de bu yönde geliştirilmesi, çocuk kitaplarından etkilice yararlanılabilmesini sağlamada yarar sağlayacaktır.

İdealize edilmiş karakterleri olan kitaplara yönelmenin çocukların özdeşim kurmasının önünde önemli bir engel olduğunun farkında olmaları gerekir. Gerek çocuk edebiyatı öğretiminde gerek hizmet içi eğitim süreçlerinde çocuk edebiyatı kitaplarına yüklenen anlamın açık ve işlevsel olmasına özen gösterilmeli bu yapıtların birer ders kitabı olmadığı ve yalnızca didaktik amaçlar için kullanılamayacağı açıklanmalıdır. Çocuk edebiyatı yapıtları ve çocuklara yönelik hazırlanan diğer kitaplar çocuğun bilişsel ve duyuşsal yönden gelişmesini destekleyecek, estetik açıdan farkındalık kazandıracak nitelikte olmalı tek amacı bilgi vermek olan kitaplarda diğer gelişim alanlarının göz ardı edildiği unutulmamalıdır.

Öğretmenlerin gerçek bir çocuğun özelliklerini taşıyan, hataları olan ancak bu hatalara çözüm arayan, düzeltmeye çalışan, gerçekçi karakterler üzerine yapılanmış kitaplara yönelmeleri gerekir. Bu seçimi gerçekleştirebilmeleri ise hizmet öncesinde ve hizmet içinde aldıkları eğitime ve çocuklara yönelik kitapları eleştirel gözle izleme ve değerlendirme süreçlerine bağlıdır.

\section{Kaynaklar}

Aslan, C. (2013). Duyarlık ve Düşünceyi Geliştirmede Çocuk/Gençlik Edebiyatı. Çoluk Çocuk Anne Baba Eğitimci Dergisi, 12, 29-32.

Black, J. B., Turner, T. J., Bower, G. H. (1979). Point of View in Narrative Comprehension, Memory, and Production. Journal of Verbal Learning and Verbal Behavior, 18(2), 187-198.

Burke, C. L., Copenhaver, J. G. (2004). Animals as People in Children's Literature. Language Arts, 81(3), 205.

Cresweell, J. W. (2013). Nitel Araştırma Yöntemleri: Beş Yaklaşıma Göre Nitel Araştırma ve Araştırma Deseni. (M. Bütün ve S. Demir, Çev.). Ankara: Siyasal Kitabevi.

Coplan, A. (2004). Empathic Engagement with Narrative Fictions. The Journal of Aesthetics and Art Criticism, 62(2), 141-152.

Hunt, P. (Ed.). (2002). Understanding Children's Literature. Routledge.

Karatay, H. (2014). Çocuk Edebiyatı Metinlerinde Bulunması Gereken Özellikler. T. Şimşek (Ed.). Kuramdan uygulamaya çocuk edebiyatı el kitabı. (s. 81-127). Ankara: Grafiker Yayınları.

Kıran, A., Kıran, Z. (2011). Yazınsal Okuma Süreçleri. Ankara: Seçkin.

Lesnik-Oberstein, K. (2004). Children's Literature: New Approaches. Springer.

Lukens, R. J., Smith, J., Coffel, C. M. (2013). A Critical Handbook of Children's Literature. Essex: Pearson Education Limited. 
Mallan, K. (2017), Children's Literature in Education. G. Noblit (Ed.). Oxford Research Encyclopedia of Education. Oxford University Press, New York.

Manguel, A. (2017). Okumanın Tarihi (F. Elioğlu, Çev.). İstanbul: YKY.

Merriam, S. B. (2009). Qualitative Research: A Guide to Design and Implementation. San Fransisco: Jossey Bass.

Nas, R. (2014). Örneklerle Çocuk Edebiyatı. Bursa: Ezgi Kitabevi.

Neville, E. (1967). Social Values in Children's Literature. The Library Quarterly, 37(1), 46-52.

Özdemir, E. (2011). Eleştirel Okuma. Ankara: Bilgi Yayıncılık.

Patton, M. Q. (2014). Nitel Araştırma ve Değerlendirme Yöntemleri. (M. Bütün ve S. B. Demir Çev.Ed.), Ankara: Pegem Akademi.

Rall, J., Harris, P. L. (2000). In Cinderella's slippers? Story Comprehension from the Protagonist's Point of View. Developmental Psychology, 36(2), 202.

Rinck, M., Bower, G. H. (1995). Anaphora Resolution and the Focus of Attention in Situation Models. Journal of Memory and Language, 34(1), 110-131.

Sever, S. (2010). Çocuk ve Edebiyat. İzmir: Tudem Yayınları

Sever, S. (2013). Çocuk Edebiyatı ve Okuma kültürü. İzmir: Tudem Yayınları.

Ural, S. (2013). Okulöncesi Çocuk Kitaplarının Tanımı. M. Gönen (Ed.) Çocuk edebiyatı (s. 33-55). Ankara: Eğiten Kitap.

Vermeule, B. (2013). Edebi Karakterlere Neden Önem Veririz? İstanbul: Alfa Yayınları.

Yalçın, A., Aytaş, G. (2014). Çocuk Edebiyatı. Ankara: Akçağ Yayınları.

Yıldııım, A., Şimşek, H. (2011). Sosyal Bilimlerde Nitel Araştırma Yöntemleri. Ankara: Seçkin Yayıncılık.

\section{Extended Abstract} Introduction

As is widely known, a linguistic text should carry particularly designated characteristics in order to be described as a 'literary work'. It becomes further crucial to consider those characteristics in any attempt to choose a text or do literature-focused activities in school settings. According to Glazer and Williams (1979), children's literary texts, hereby children's literature books, should have a good topic, well-built fiction, welldeveloped characters, and a meaningful theme as well as an artistic style, language, and expression to support children's imagination (in Lesnik, 2004). In a similar way, Sever (2013) reminds us the responsibilities of children's literature books with an emphasis on their significance in raising children who possess mentally and emotionally stable personalities and have internalized the values of democratic culture. He clearly signifies that these outcomes can be achieved through the characters created, particularly, the protagonist as well as the main and implicit themes handled in a children's literature book. In short, it is understood that such elements of literary works as explicit and implicit theme, style, fiction and characters, through which the meaning is carried out in a book, should be considered in the evaluation of literary texts.

This research article aims to determine how preschool teachers choose children's literature books in terms of characters in order to do reading activities in pre-school settings. Kıran and Kıran (2011) emphasize that the main character or the protagonist is a must for all kinds of narrative types (novel, story, fairy tale etc.), and indicate that he/she is positioned in the center as the formative element of the narrative. Protagonist is regarded as the main character for the consistency and continuity of the story, in other words; he/she is the 'locomotive' of the narrative. Implicit and explicit themes of the text is provided through the characters and the incidents they experience. In short, characters who are the reflections of real life, play an active role in establishing a relationship between the literary text and real life.

"Ability of children to empathize with the positive characters in a book and to get into the narrative depends highly on the fact that the characters are presented in a reliable, credible and realistic way besides characters' being in the same age group with the reader" (Karatay, 2014: 103). Nas (2014) argues that the characters presented in children's literature books should reflect the contradictory aspects of human life such as strong and weak, positive and negative personalities. He emphasizes the importance of developing characters similar to the ones that children can encounter in real life. Therefore, he objects to any idealization in children's literature books and offers that characters should not be depicted as being superior or invincible. To achieve this 
aim in children's literature books, authors should prefer the personalities of an ordinary child, not the 'ideal' personalities that they want to see in a 'perfect' child. Moreover, it is one of the desired features of the children's literature books that characters experience changes throughout the story, and these changes are convincing for the child who is the intended listener or the reader of the book. It is also possible to see the animals that children may sympathize with are positioned as the main characters in children's literature books. It is believed that animal characters can have an emotional identification although not a physical one.

Method

This research is designed as a case study which is among the qualitative methods. The data were analyzed by descriptive coding scheme. Firstly, the author of this article aimed to form categories, and then grouped the findings under certain extensive themes. Categories were classified under these headings: "Character type", "Transfer to real life", "Positive character features" and "What is the message in the last page?". Finally, themes were grouped under such headings as "Character Attributes" and "Behavior and Values Education".

\section{Result and Discussion}

Teachers have expressed that they act according to some criteria regarding the elements of internal and external structures of text. It has been found out that pre-school teachers tend to choose didactic texts for the activities they do with children. The aim of using didactic texts, according to teachers, is to teach children some simple rules in life and to raise 'good children or good citizens' who always follow the given rules in a society which were often expressed by teachers either explicitly or implicitly. However, children's literature books should aim to free children with an effort to enable them to think through implicit themes. If the aim is just the behavior change, then the intended application of the book contradicts with the quality of children's literature.

Characters, as the most effective elements for children to interact with the book in the reading process, are crucial elements that should be emphasized in the selection of books. However, it is understood that teachers approach characters differently during the book selection phase. Teachers think that children tend to empathize with the characters and to imitate them. From these considerations, we have come to the conclusion that teachers are inclined to choose books with characters that will make it easier for children to gain certain behaviors. In addition, it is seen that characters are sometimes not even considered as a criterion for choosing a children's literature book to be used in preschool settings.

As a result, it is concluded that teachers' selection criteria for books are structured around the aim of behavior and values education. However, literature signifies that this criteria is not aligned with the principles of children's literature. Finally, it should be emphasized that such an approach used by teachers contradicts with the aims of using children's literature books, which is raising individuals who can adapt to the changing conditions of our time and can communicate with contemporary cultures by recognizing universal and local values. 